\title{
Integrated Marketing Communication Pada Usaha Industrial Internet of Things - Machine Vision
}

\author{
Monika Teguh*, Aulialukita Niantiara, \& Andrea Hartansa \\ Universitas Ciputra Surabaya, CitraLand CBD Boulevard, Surabaya Jawa Timur 60219 \\ *e-mail : monika.teguh@ciputra.ac.id
}

\begin{abstract}
Marketing communication is a study that develops along with the development of new types of industries, such as Industry 4.0. The existence of a marketing communication study for this new type of industry, that is being seeded by the Indonesian Government, is crucial for the future development of Indonesian industry. Therefore, the purpose of this study is to describe an integrated marketing communication strategy that is applied to industry 4.0, especially in the field of Industrial Internet of Things. The focus of this research is to examine integrated marketing communication strategies to develop awareness, encourage buying interest, as well as encourage sales to companies that provide Industrial Internet of Things, with a locus in a company engaged in this field, namely Machine Vision. This research uses qualitative research methods with semi-structured interview data collection techniques. The results of this study indicate that the integrated marketing communication strategy that contributes positively to the type of industry 4.0 consists of two groups, namely primary and secondary. The main groups consist of digital marketing, direct marketing, and public relations. Meanwhile, the secondary group consists of sales promotion and personal selling. Marketing communication activities of the main groups have a significant impact both on increasing awareness and encouraging buying interest and product selling. While activities in the secondary group function as a complement or support to the main activities.
\end{abstract}

Keywords: integrated marketing communication; industry 4.0; internet of things; Machine Vision

\section{ABSTRAK}

Komunikasi pemasaran merupakan kajian yang berkembang seiring dengan berkembangnya jenis-jenis industri baru seperti Industri 4.0. Keberadaan kajian komunikasi pemasaran untuk jenis industri baru yang sedang digadang-gadang oleh Pemerintah Indonesia ini, menjadi krusial bagi pengembangan industri Indonesia kedepan. Maka dari itu tujuan penelitian ini adalah untuk menjabarkan strategi komunikasi pemasaran terpadu yang diterapkan pada industri 4.0, khususnya bidang Industrial Internet of Things. Lebih jauh, penelitian ini mengkaji strategi komunikasi pemasaran terpadu (Integrated Marketing Communication/IMC) untuk mengembangkan awareness, mendorong minat beli, maupun mendorong terjadinya penjualan pada perusahaan yang menyediakan Industrial Internet of Things, dengan lokus pada sebuah perusahaan yang bergerak di bidang ini yaitu Machine Vision. Penelitian ini menggunakan metode penelitian kualitatif dengan teknik pengumpulan data wawancara semi terstruktur. Hasil dari penelitian ini menunjukkan strategi IMC yang berkontribusi positif pada jenis industri 4.0 terdiri atas dua kelompok, yaitu utama dan sekunder. Kelompok utama terdiri dari digital marketing, direct marketing, dan public relations. Sedangkan kelompok sekunder terdiri dari sales promotion dan personal selling. Aktivitas komunikasi pemasaran dari kelompok utama memberikan dampak signifikan baik untuk peningkatan awareness, serta pendorongan minat beli dan penjualan. Sedangkan aktivitas pada kelompok sekunder berfungsi sebagai pelengkap atau pendukung dari aktivitas utama.

Kata kunci: komunikasi pemasaran terpadu, industri 4.0, internet of things, Machine Vision 


\section{Latar Belakang}

Studi ini akan membahas tentang strategi IMC yang sesuai bagi industri 4.0, khususnya usaha jasa Industrial Internet of Things (IIoT). Hal ini menjadi penting untuk dibahas karena terdapat peningkatan kebutuhan perusahaan konvensional untuk beralih ke sistem digital. Namun sayangnya, perusahaan konvensional itu sendiri masih mengalami kesulitan untuk berhubungan dengan penyedia jasa IIoT sendiri. Maka dari itu diperlukan suatu kajian mengenai strategi IMC untuk usaha jasa IloT yang diambil dari best practice yang telah pernah dilakukan, agar perindustrian di Indonesia tidak tertinggal dalam pengembangan sistem digital di era industri 4.0.

Para pelaku dunia industri telah menyadari pentingnya melakukan sinergi terhadap berbagai bentuk komunikasi dalam upaya untuk mengembangkan pemasaran perusahaan, sehingga kajiankajian komunikasi pemasaran terpadu atau integrated marketing communication (IMC) terus berkembang (Morissan, 2010). Saat ini telah banyak dilakukan penelitian mengenai komunikasi pemasaran terpadu. Beberapa diantaranya membahas penerapan komunikasi pemasaran terpadu untuk produk berupa barang seperti yang dilakukan oleh Chrismardani (2014) yang membahas IMC pada UMKM, Kusniadji yang membahas IMC pada bisnis consumer goods (2017), serta Teguh, Benita dan Dewi yang membahas IMC untuk produk snack (2020). Sedangkan beberapa penelitian lain tentang komunikasi pemasaran terpadu membahas penerapannya pada bidang jasa seperti yang dilakukan oleh Adhianti dan Herlinda (2020) yang melakukan penelitian IMC untuk museum, Andretti dan Arifin (2016) yang meneliti pada PT DBL Indonesia, serta Rismayanti (2016) yang meneliti pada PT Halo Rumah Bernyanyi.
Kebanyakan penelitian tentang komunikasi pemasaran terpadu yang ada saat ini masih berkutat pada jenis-jenis usaha konvensional yang memang telah lama ada. Namun saat ini juga berkembang aktivitas industri dari bentuk konvensional menuju ke bentuk daring (Rahargo \& Jannah, 2020). Maka dari itu diperlukan kajian baru komunikasi pemasaran terpadu untuk jenis usaha baru yang disebut sebagai industri 4.0, seperti yang akan dijabarkan dalam penelitian ini.

Industri 4.0 merupakan perubahan besar-besaran dari keseluruhan aspek produksi yang ada dalam industri melalui penggabungan teknologi digital dan internet dengan industri konvensional $(\mathrm{H}$. Prasetyo \& Sutopo, 2018). Industri 4.0 mengupayakan transformasi serta pengembangan dari sebagian besar aspek produksi di industri-industri dengan mengintegrasikan antara teknologi digital dengan internet. Dalam dunia industri, yang menjadi pilar penting adalah manusia, proses, dan mesin. Maka dari itu, Industri 4.0 mengoptimalkan ketiga pilar tersebut menjadi solusi efektif di dunia industri dengan menghubungkan ketiganya melalui penggabungan teknologi digital dengan internet. Dengan kata lain, sumber daya manusia harus beradaptasi dengan mesin dan teknologi untuk mengimbangi perkembangan zaman serta persaingan (Rusmana, 2019).

Secara teknis, definisi Industri 4.0 adalah integrasi dari Cyber Physical System (CPS) dan Internet of Things and Services (IOT dan IOS) ke dalam proses industri meliputi manufaktur dan logistik serta proses lainnya. Artinya, industri 4.0 adalah penggabungan antara dunia maya dan dunia nyata dengan sebuah komputasi atau koneksi (Kagermann et al., 2016). Perkembangan aktivitas industri secara daring ini didorong dengan jumlah pengguna internet Indonesia yang terus 
tumbuh, dimana sampai dengan kuartal II 2020 sudah terdapat 196,7 juta jiwa. Berbagai aktivitas industri yang dulunya dilakukan secara konvensional, mulai berubah ke arah digital yang lebih mudah dan praktis (Firmansyah, 2018). Beberapa manfaat dari industri 4.0 antara lain meningkatkan daya saing bisnis, meningkatkan produktivitas, meningkatkan pendapatan, meningkatkan kualitas sumber daya manusia dan pengelolaan sumber daya teknologi, mengoptimasi proses manufaktur, pengembangan teknologi eksponensial, dan layanan pelanggan (customer service) yang lebih baik (Gilchrist, 2016).

Menghadapi perkembangan ini, pemerintah Indonesia tengah berkomitmen untuk meningkatkan posisi daya saing Indonesia terhadap negaranegara lain. Untuk mencapai tujuan tersebut, salah satu solusi yang digadanggadang oleh Kementerian Perindustrian (Kemenperin) adalah dengan memacu industri dalam negeri agar terus melakukan inovasi dalam menghadapi industri 4.0 (Satya, 2018). Program untuk memacu perkembangan industri di era 4.0 disebut dengan Making Indonesia 4.0. Program ini berfokus pada pengembangan lima jenis industri yaitu food and beverages, otomotif, tekstil, kimia, dan elektronik yang diintegrasikan dengan teknologi digital (Adrian, 2019). Salah satu teknologi yang dapat diintegrasikan pada industri-industri tersebut agar mampu bersaing di era 4.0 adalah Industrial Internet of Things (IIOT). IloT adalah cara untuk mendapatkan visibilitas dan pengetahuan yang lebih baik ke dalam aset operasi perusahaan melalui integrasi sensor mesin, middleware, perangkat lunak, komputasi cloud dan sistem penyimpanan data (Gilchrist, 2016). IloT dilaksanakan dengan membuat jaringan perangkat yang tersambung ke internet yang dapat mengumpulkan dan bertukar data menggunakan sensor yang telah ditanamkan (Ustundag \& Cevikcan, 2017). Di Indonesia, penggunaan IIoT ini telah terbukti memberikan kontribusi positif pada pertumbuhan ekonomi. Dua sektor yang telah terdampak secara signifikan adalah industri pariwisata dan ritel (Widagdo \& Rofik, 2019). Namun sayangnya banyak pelaku industri menghadapi kesulitan untuk menerapkan IIoT pada usahanya. Terdapat beberapa faktor yang menyebabkan kesulitan tersebut antara lain pengaturan alur komunikasi, pengelolaan teknologi, keamanan dan privasi pengguna, pekerjaan yang membutuhkan keahlian khusus, peraturan yang berlaku, dan budaya penggunaan. Hal-hal ini jika ingin diatasi sendiri oleh perusahaan akan membutuhkan banyak biaya dan sumber daya manusia (Uslu et al., 2019). Maka dari itu keberadaan perusahaan jasa yang bisa membantu industri-industri di Indonesia untuk menerapkan IloT menjadi dibutuhkan. Namun permasalahan muncul dimana industri jenis ini walaupun sudah mulai dibutuhkan, belum banyak dikenal oleh masyarakat. Tidak banyak pelaku industri konvensional yang menyadari keberadaan dari jasa IIoT, padahal mereka sudah mulai membutuhkan jasa tersebut karena tidak dapat menciptakan dan mengelola sistem sendiri. Berdasarkan permasalahan ini, perusahaan-perusahaan jasa IloT membutuhkan strategi komunikasi pemasaran terpadu untuk memperkenalkan perusahaannya secara luas. Hal ini membuat kajian akan IMC bagi perusahaan jasa $I l o T$ penting untuk dilakukan.

Salah satu usaha jasa yang berfokus pada IloT untuk optimasi kebutuhan industri manufaktur adalah Machine Vision. Machine Vision adalah perusahaan yang berbasis di Surabaya dengan tujuan 
modernisasi dan digitalisasi industri Indonesia, untuk membantu perusahaanperusahaan agar tumbuh, memaksimalkan produktivitas, dan mengoptimalkan efisiensi dalam proses bisnis dan kebutuhan mereka. Berdiri sejak 2016, produk yang dihasilkan oleh Machine Vision antara lain adalah headmounted, software untuk mengolah jutaan data perusahaan. Machine Vision memastikan transparansi dalam kinerja pabrik aktual yang memungkinkan pengambil keputusan untuk menemukan solusi dari sebuah masalah apapun yang mengarah pada peningkatan produktivitas.

Machine Vision secara khusus dijadikan lokus dalam penelitian ini karena keberhasilannya dalam melaksanakan komunikasi pemasaran terpadu yang membuatnya dipercaya oleh klien-klien dari perusahaan besar. Beberapa perusahaan besar telah menjadi klien Machine Vision, antara lain Telkom Indonesia, Nabati, Nutricia, POM Consultants, dan Sarihusada. Machine Vision juga telah mendapatkan nominasi "Rintisan Teknologi Industri 2018 Award" oleh Kemeperin pada 2018 lalu dan terpilih sebagai salah satu teknologi rintisan industri terbaik. Maka dari itu komunikasi pemasaran terpadu dari Machine Vision ini dapat dikaji lebih lanjut sebagai salah satu best practice dari jenis industri 4.0.

IMC adalah suatu proses mengembangkan dan mengimplementasikan berbagai kegiatan komunikasi persuasif kepada konsumen dan calon konsumen secara berkesinambungan (Chrismardani, 2014). IMC menjadi krusial bagi sebuah perusahaan karena mampu mengambil aspirasi dari masyarakat, klien, pelanggan, dan patner, untuk menjadi dasar pengambilan keputusan perusahaan (Ginting, 2015). IMC juga berfungsi untuk membina hubungan baik dengan pelanggan melalui berbagai programprogram komunikasi pemasaran (Permata \& Rahayu, 2015). Lebih jauh lagi IMC kini dipandang sebagai suatu proses yang memanfaatkan elemen-elemen promosi sebagai suatu kesatuan untuk menciptakan efek komunikasi yang sinergis (Rehman \& Ibrahim, 2011). Terdapat Langkah-langkah yang dapat dilakukan agar IMC berjalan dengan efektif yaitu mengenali target market, menentukan tujuan IMC, menyusun pesan, menentukan channel, menetapkan anggaran, dan merancang bauran komunikasi pemasaran atau IMC mix (Keke, 2016).

Terdapat berbagai jenis IMC mix yang dapat diturunkan menjadi programprogram sesuai karakteristik dan kebutuhan perusahaan. Seperti pada PT DBL Indonesia, mereka melaksanakan komponen public relations, sales promotion, personal selling, dan advertising (Andretti \& Arifin, 2016). Sedangkan pada PT Halo Rumah Bernyanyi menjalankan keempat komponen tersebut ditambah dengan direct marketing (Rissmayanti, 2016). Pada PT Expand Berlian Mulia dilakukan komponen-komponen seperti yang dilaksanakan kedua perusahaan sebelumnya, namun dengan tambahan publisitas dan event (Kusniadji, 2017). Secara terperinci komponen dari IMC Mix terdiri atas tujuh komponen. Komponen pertama adalah advertising. Advertising atau iklan merupakan upaya perusahaan yang melakukan komunikasi tentang suatu produk atau jasa, organisasi atau perusahaan, dan suatu ide yang bersifat nonpersonal sehingga tidak ada respon timbal balik secara langsung (Morissan, 2010). Advertising adalah bentuk komunikasi berbayar yang dilakukan oleh oleh individu atau perusahaan dengan tujuan untuk mempengaruhi orang untuk 
berpikir atau bertindak dengan cara tertentu atau memberikan informasi (Green, 2011). Secara umum, advertising memiliki nilai karena memberikan beberapa fungsi dari komunikasi. Fungsi pertama dari iklan yaitu informing, dimana iklan meningkatkan kesadaran konsumen akan merek baru. Advertising berfungsi untuk memberikan informasi dan edukasi mengenai manfaat, keunggulan dan fitur tentang merek tersebut kepada konsumen. Fungsi berikutnya dari iklan adalah persuading, untuk mempengaruhi konsumen agar membeli dan mencoba merek yang ditawarkan dengan menggunakan efek emosi positif konsumen. Fungsi iklan lainnya adalah reminding, untuk mempengaruhi pergantian merek dengan cara mengingatkan konsumen akan merek tertentu. Kemudian fungsi terakhir dari iklan adalah adding value yang bertujuan untuk mengubah persepsi konsumen terhadap nilai suatu produk.

Komponen IMC Mix berikutnya adalah digital marketing. Digital marketing adalah semua kegiatan pemasaran yang dilakukan dalam jaringan seperti melalui situs web, YouTube, Instagram, Facebook, dan lainnya. Pada umumnya, digital marketing bersifat interaktif dimana para konsumen dapat mendapatkan respon secara langsung dari pengirim pesan yaitu perusahaan atau organisasi (Chitty et al., 2015). Beberapa keuntungan dari kegiatan ini diantaranya adalah mempunyai dan menemukan target pasar sendiri, aksesbilitas yang mudah, dapat mengetahui perilaku konsumen melalui interaksi, biaya yang efektif, serta dapat memahami perubahan konsumen.

Komponen berikutnya dari IMC Mix adalah direct marketing. Direct marketing merupakan upaya suatu organisasi atau perusahaan untuk melakukan kontak langsung dengan konsumen secara interaktif tanpa menggunakan perantara. Seorang yang melakukan direct marketing menggunakan beberapa media seperti telepon, e-mail, dan lainnya. Tujuannya adalah untuk mendapatkan respon langsung dari konsumen tersebut, maka dari itu direct marketing bersifat interaktif, yaitu komunikasi dua arah (B. D. Prasetyo et al., 2018). Direct marketing bukan sesuatu yang hanya bisa dibangun begitu saja, melainkan sesuatu yang direncanakan dan berdasarkan pemahaman tujuan yang akan dicapai (Chitty et al., 2015). Terdapat beberapa komponen direct marketing untuk mencapai tujuan perusahaan. Komponen pertama yaitu objektifitas yang menentukan tujuan dari kegiatan pemasaran langsung yang ingin dicapai. Berikutnya adalah media, sebagai alat untuk mendapatkan materi di depan penonton atau konsumen. Kemudian komponen kreatif, yang mencakup cara bagaimana pesan tersebut disampaikan ke penonton atau konsumen. Komponen berikutnya adalah database, yaitu sistem untuk menyimpan informasi mengenai konsumen dan dapat menentukan pemilihan target konsumen. Komponen terakhir adalah implementasi dari pemasaran langsung, dari pembuatan pesan hingga pengiriman pesan.

Sales promotion merupakan komponen IMC Mix selanjutnya. Sales promotion adalah kegiatan yang terdiri dari insentif jangka pendek untuk meningkatkan pembelian atau penjualan suatu produk dan layanan termasuk promosi konsumen, iklan dan penjualan (Kotler \& Lane, 2016). Sales promotion adalah alat untuk promosi, merujuk pada insentif apa pun yang digunakan oleh produsen dalam kurun waktu yang singkat untuk mendorong distributor seperti grosir, pengecer ataupun mendorong konsumen untuk membeli produk atau 
jasa perusahaan. Selain untuk waktu dengan jangka yang singkat, sales promotion dapat digunakan untuk menciptakan loyalitas jangka panjang dan preferensi merek (Chitty et al., 2015).

Bentuk komponen IMC Mix selanjutnya adalah personal selling. Personal selling adalah komunikasi perorangan ketika penjual memberikan informasi, edukasi dan menawarkan produk atau jasa yang dijual oleh perusahaan (Chitty et al., 2015). Personal selling merupakan tenaga perusahaan untuk menciptakan dan mengkomunikasikan nilai pelanggan melalui interaksi pribadi antar pelanggan. Orang-orang yang melakukan kegiatan ini biasa disebut agen, konsultan sales, manajer distrik, dan lain-lain (Kotler \& Armstrong, 2012).

Salah satu komponen IMC Mix lainnya adalah public relations. Public relations adalah upaya untuk membangun hubungan baik dengan berbagai pihakpihak luar perusahaan dengan memperoleh publisitas yang baik, membangun citra perusahaan yang baik, dan menangani atau menghindari kabar, cerita, dan peristiwa yang tidak menguntungkan bagi perusahaan (Chitty et al., 2015). Dalam public relations, terdapat pembagian pekerjaan yang memiliki fokus terhadap hubungan perusahaan dengan konsumen yang dinamakan Marketing Public Relations (MPR). Public relations memiliki beberapa fungsi. Fungsi pertama adalah press relation, yang membuat dan menempatkan berita yang layak dan menarik untuk media sebagai penarik perhatian kepada konsumen, produk, dan jasa. Fungsi berikutnya adalah product publicity untuk mempublikasi produk lebih spesifik. Selain itu PR juga berfungsi sebagai public affair untuk menjalin hubungan baik dengan komunitas lokal maupun internasional. PR juga berfungsi dalam hal lobbying untuk menjalin hubungan baik dengan pemerintahan untuk memberi pengaruh terhadap regulasi atau aturan. Investor relation juga merupakan fungsi PR untuk menjalin hubungan baik dengan shareholder dan komunitas-komunitas keuangan yang berkaitan dengan perusahaan. PR juga diperlukan untuk melakukan development, dimana PR bekerja sama dengan anggota organisasi nirlaba untuk meningkatkan dukungan atau bantuan relawan. PR juga mencakup fungsi sponsorship, yang merupakan salah satu aspek penting dalam komunikasi pemasaran karena perannya dalam investasi dan pendanaan di sebuah kegiatan organisasi. Kegiatan sponsorship berguna untuk meningkatkan kesadaran merek, meningkatkan citra merek, dan meningkatkan volume penjualan (Chitty et al., 2015). Pada dasarnya, sponsorship memiliki dua kegiatan utama, yaitu pertukaran atau barter antara pihak sponsor (perusahaan) dan yang disponsori (kegiatan organisasi), serta asosiasi pemasaran oleh pihak sponsor.

Berdasarkan uraian yang dijelaskan diatas, maka penelitian ini bertujuan untuk menjabarkan implementasi IMC pada perusahaan Machine Vision. Hal ini menjadi urgen untuk dibahas karena belum banyaknya literatur yang membahas mengenai penerapan IMC pada perusahaan yang bergerak di bidang IIOT. Sedangkan Machine Vision dipilih sebagai subjek penelitian karena keberhasilannya yang dapat menjadi best practice untuk dikaji. Diharapkan melalui penelitian ini, para pembaca akan mendapatkan tambahan kajian baru di bidang komunikasi pemasaran, serta dapat menjadi masukan bagi pelaku dan calon pelaku usaha di bidang yang sejenis. 


\section{Metode}

Penelitian ini menggunakan metode kualitatif deskriptif untuk memperoleh hasil yang diinginkan. Penelitian deskriptif bertujuan untuk menjelaskan dan mendeskripsikan situasi atau kegiatan yang sedang diteliti dan juga merupakan akumulasi dari sebuah database yang tidak mencari atau menjelaskan sebuah korelasi, hipotesis, membuat prediksi atau mencari implikasi (Daniel \& Sam, 2011). Penelitian kualitatif deskriptif cenderung memaparkan sebuah fenomena atau kejadian secara detail dengan tidak menggunakan teori maupun hipotesis (Noor, 2016). Tujuan dari penelitian deskriptif salah satunya adalah untuk menghasilkan penggambaran suatu masalah atau fenomena yang sedang diteliti dan bersifat naratif sehingga, penelitian memiliki gambaran jelas mengenai fenomena yang sedang diteliti (Kuada, 2016).

Metode pengumpulan data yang digunakan dalam penelitian ini adalah wawancara dan dokumentasi. Wawancara adalah sebuah proses interaksi secara langsung antara pencari data dengan sumber data dalam hal ini yaitu informan atau narasumber yang bertujuan untuk mengumpulkan informasi terkait penelitian yang sedang diteliti dengan cara mengajukan pertanyaan langsung (Yusuf, 2016). Penelitian ini menggunakan metode wawancara semi terstruktur, agar peneliti bisa menggali lebih dalam mengenai informasi yang ingin didapat. Sumber data untuk wawancara adalah informan penelitian. Informan merupakan seseorang yang menjadi narasumber penelitian deskriptif atau dalam kata lain merupakan seseorang yang harus digali informasinya mengenai suatu fenomena untuk mengumpulkan data. Pemilihan informan untuk pengumpulan data dari penelitian ini berdasarkan pada subyek-subyek yang memiliki data perusahaan, menguasai permasalahan yang diteliti dan yang mampu memberikan informasi akurat serta detil mengenai permasalahan maupun data perusahaan. Adapun informan yang menjadi narasumber dari penelitian ini adalah co-founder sekaligus owner dari Machine Vision. Co-founder Machine Vision merupakan orang yang merumuskan strategi IMC dari Machine Vision, sehingga penting digali informasi mengenai perancangan strategi IMC darinya. Selain co-founder, marketing officer Machine Vision juga diwawancara dalam penelitian ini. Marketing officer adalah orang yang bertanggung jawab dalam pelaksanaan strategi IMC di Machine Vision, sehingga bisa diperoleh data pelaksanaan strategi IMC darinya. Berikutnya narasumber yang juga diwawancara adalah person in charge (PIC) dari perusahaan klien Machine Vision. PIC perusahaan klien ini adalah orang yang merasakan langsung strategi IMC yang dilaksanakan oleh Machine Vision, sehingga pengalamannya dapat menjadi sumber data bagi penelitian ini. Kemudian diwawancara juga business development dari VO Group yang menjadi narasumber ahli. Narasumber ahli diperlukan sebagai pemberi masukan untuk triangulasi data sehingga dalam penelitian ini dilakukan juga wawancara kepada narasumber ahli. Sedangkan dokumentasi merupakan kegiatan mengambil gambar sebagai hasil dan bukti proses penelitian yang dilakukan oleh peneliti. Hasil dari dokumentasi nantinya akan digunakan untuk menguji dan menafsirkan proses penelitian (Anggito \& Setiawan, 2018). Sumber data untuk dokumentasi diambil dari website, media sosial maupun arsip yang dimiliki oleh Machine Vision.

Untuk menyajikan data yang mudah dipahami, teknik analisis data yang 
digunakan dalam penelitian ini adalah model interaktif dari Miles dan Huberman. Model ini menjelaskan, analisis data memiliki empat langkah yang perlu dilakukan yaitu: pengumpulan data, reduksi data, display data, serta penarikan kesimpulan dan verifikasi (Herdiansyah, 2010).

Dalam upaya menjaga kualitas penelitian, dilakukan juga proses validitas penelitian. Validitas didefinisikan sebagai sebuah ukuran untuk menyeimbangkan data saat observasi dengan data yang nantinya ditulis oleh peneliti. Proses validitas dalam penelitian ini menggunakan teknik triangulasi sumber, yaitu penggabungan antara metodemetode pengumpulan data dengan sumber data yang digunakan tentang fenomena yang diteliti dari beberapa sisi yang berbeda (Anggito \& Setiawan, 2018). Triangulasi sumber menekankan penggunaan data-data dari persepsi dan sisi lain dan digunakan sebagai pembanding saat pengecekan data (Fitrah \& Luthfiyah, 2018).

\section{Pembahasan}

Dalam perkembangan industri 4.0, dibutuhkan strategi IMC yang tepat agar usaha jenis baru ini dapat menembus pasar dengan lebih baik. Perlu dipahami bahwa banyak target pasar yang bahkan belum memahami berbagai jenis industri 4.0. Maka dari itu penetrasi pasar menjadi krusial untuk dipikirkan dalam strategi IMC. Selain itu karena target pasarnya juga masih belum luas, maka penjagaan klien yang sudah ada merupakan hal yang juga harus menjadi perhatian pada penerapan IMC di industri 4.0.

Secara khusus subyek dalam penelitian ini adalah Machine Vision yang berak di industri 4.0. Agar pembahasan dalam penelitian ini dapat dijabarkan lebih jelas, maka sebelumnya akan dibahas mengenai Machine Vision sendiri. Perlunya penjabaran Machine Vision ini adalah pembaca juga memahami industri yang belum banyak dikenal oleh masyarakat luas. Machine Vision adalah perusahaan yang berupaya meningkatkan proses dalam suatu industri tanpa menggantikan atau menghilangkan peran manusia. Machine Vision mengawali usahanya dengan kesadaran bahwa untuk meraih manufacturing excellence, perusahaan perlu untuk mengembangkan sumber daya manusia (people excellence), meningkatkan proses kerja (process excellence) dan mengoptimalisasi operasional (operational excellence). Tahap-tahap untuk meraih manufacturing excellence ini tentunya menghasilkan data dalam jumlah banyak. Banyaknya data tersebut menyebabkan perusahaan akan kesulitan untuk mengolah data, yang berujung pada kesulitan untuk melakukan aktivitas maupun mengambil keputusan krusial. Disinilah Machine Vision berperan untuk mendigitalisasi data yang ada pada perusahaan sehingga dapat ditampilkan dengan mudah. Dengan digitalisasi ini, seluruh lini dalam perusahaan bisa mendapatkan informasi secara cepat yang dapat digunakan untuk meningkatkan efektivitas perusahaan. Selain meningkatkan efektivitas perusahaan, para eksekutif juga dapat memperoleh data yang dibutuhkan, sehingga pengambilan keputusan dapat dilakukan dengan cepat dan akurat.

Berdasarkan wawancara dengan cofounder dan marketing officer dari Machine Vision, salah satu hal yang menjadi tantangan bagi Machine Vision adalah adanya kesulitan untuk merubah kebiasaan atau pola kerja manual konvensional menjadi digital di Indonesia. Meskipun sudah terdapat teknologi yang canggih, namun jika sumber daya manusia tidak siap untuk menggunakannya, maka 
teknologi itu tidak akan berguna. Maka dari itu, Machine Vision yang merupakan perusahaan asli Indonesia, yang dikembangkan oleh orang-orang Indonesia, yang sudah memahami habit dari masyarakat Indonesia sendiri, mengusung misi untuk merombak industri di Indonesia melalui pendekatan yang humanis. Disini Machine Vision menawarkan jasanya untuk membantu perusahaan mengadopsi "Industrial Internet", dimana yang menjadi penekanannya bukanlah pada penggunaan teknologi yang canggih, namun penyediaan teknologi yang sederhana, namun memecahkan permasalahan dan dapat berkolaborasi dengan sumber daya manusia yang dimiliki perusahaan.

Dalam rangka mencapai tujuan perusahaan tersebut, co-founder Machine Vision menjelaskan bahwa Machine Vision menyediakan berbagai layanan yang dapat disesuaikan dengan kebutuhan perusahaan klien. Machine Vision menawarkan jasa untuk pembuatan platform yang komprehensif, dimana Machine Vision mampu menjangkau seluruh komponen manufaktur untuk meraih potensi optimal dari perusahaan. Platform yang dirancang oleh Machine Vision dipersonalisasi untuk masingmasing perusahaan, dengan memanfatkan big data. Ujungnya adalah perusahaan klien mampu mengambil keputusan akurat berdasarkan data yang valid, menginovasi sistem produksi lewat operational excellence sehingga mampu meningkatkan daya saing perusahaan, dan mendorong sumber daya manusia menjadi 'scale up enablers' dari teknologi yang telah diimplementasikan. Platform yang disediakan oleh Machine Vision dibagi menjadi tiga sasaran yaitu untuk meningkatkan kapabilitas sumber daya manusia dalam perusahaan, meningkatkan proses kerja dalam perusahaan, serta menjaga reliabilitas sistem dalam perusahaan. Platform untuk meningkatkan kapabilitas sumber daya manusia dalam perusahaan antara lain:

a. Clev

Merupakan program yang dirancang berdasarkan kebutuhan pengembangan sumber daya manusia perusahaan. Disini materi pelatihan untuk pengembangan soft skill maupun hard skill dikemas dalam augmented reality, virtual reality, dan fitur pembelajaran berbasis kolaborasi. Program ini juga dilengkapi dengan fitur analitik agar mentor atau pelatih dapat memantau pengembangan karyawan.

b. Viretra

Viretra merupakan program untuk mengembangkan kemampuan karyawan pada skill yang memerlukan praktik. Program ini dapat digunakan untuk pelatihan pada pekerjaan seperti assembly, maintenance, dan desain. Keunggulan dari program ini adalah karyawan dapat merasakan langsung sensasi praktik pelatihan melalui augmented reality dan virtual reality, tanpa perlu disediakan bahan atau peralatan riil. Hal ini tentunya lebih efisien daripada pelatihan konvensional.

c. EcadinVR

Program ini dikhususkan untuk melatih karyawan mengenai hal-hal manajerial. Dilengkapi dengan fitur university enterprise untuk mempelajari sistem manajamen secara interaktif, augmented reality untuk pembelajaran berbasis observasi, dan virtual reality untuk latihan kepemimpinan berbasis praktik. 
Platform untuk meningkatkan proses kerja dalam perusahaan antara lain:

a. OEE Manufacturing Analytic OEE (Overall Equipment Effectiveness) Manufacturing Analytic merupakan program yang diperuntukkan bagi perusahaan yang memiliki beberapa lokasi pabrik/plant. Program ini memungkinkan data dari berbagai lokasi untuk dapat ditampilkan dalam satu dashboard. Data yang dianalisis dalam program ini utamanya adalah data-data terkait proses produksi, sehingga bisa dipantau atau dicari solusi jika ada hambatan.

b. Continuos Improvement Tracker

Program ini dirancang untuk melacak kinerja dari karyawan perusahaan. Disini dapat dilihat perkembangan dari ide hingga sampai pada implementasinya, sehingga para pelaksana di lapangan dapat melakukan continuous improvement. Dengan program ini, perusahaan dapat meminimalisir pekerjaanpekerjaan yang terbengkalai karena tidak terlacak perkembangannya.

c. Quality Control Optimization

Program ini merupakan program quality control digital yang digunakan untuk optimasi waktu dan kualitas produksi. Program ini juga dapat mendorong berkurangnya material waste dan melacak barang dari keseluruhan proses produksi. Dengan menggunakan program ini, perusahaan dapat mengontrol kualitas produksi sehingga produk yang dihasilkan sesuai standar, dengan proses yang lebih efisien.

Sedangkan platform untuk menjaga reliabilitas sistem dalam perusahaan antara lain:

\section{a. Smart Warehouse}

Program ini merupakan program untuk pelacakan inventaris pada gudang-gudang

perusahaan.

Kesulitan untuk mendata inventaris gudang karena banyaknya persediaan produk dan cepatnya perputaran pengiriman dapat diatasi dengan program ini. Penggunaan program Smart Warehouse ini juga dapat menekan kehilangan barang, meningkatkan pemenuhan pesanan dan mengurangi waktu siklus pemesanan.

b. Electronic Batch Records

Program ini khusus dirancang bagi perusahaan yang ingin memenuhi standar Good Manufacturing Practices (GMP). Dalam program ini didokumentasikan setiap detil proses manufaktur, seperti menyimpan data material yang digunakan, proses pembuatan produk, dan kegiatan yang dilakukan selama proses produksi secara real time. Dengan adanya program ini, maka perusahaan dapat lebih mudah untuk memberikan bukti dalam pemenuhan standarisasi dari pemerintah, mengurangi potensi kesalahan akibat kelalaian manusia, memastikan proses produksi sesuai dengan alur yang ditetapkan, menunjukkan transparansi proses produksi, menekan biaya operasional, menekan limbah, serta meningkatkan kualitas produksi.

\section{c. Short Interval Control}

Program ini dapat diaplikasikan untuk koordinasi antar departemen atau unit bisnis dalam perusahaan. Melalui program ini, data dari berbagai unit bisnis atau departemen dapat disatukan dalam satu dashboard. Hal ini memungkinkan antar departemen /unit bisnis dapat saling mengakses data dari departemen/unit bisnis lain sesuai kebutuhan. Dengan adanya program ini, maka waktu untuk 
berkoordinasi menjadi lebih efisien dan dapat mendorong kinerja dari masing-masing departemen/unit bisnis.

Berdasarkan informasi dari marketing officer Machine Vision, keseluruhan program yang disediakan oleh Machine Vision ini memungkinkan perusahaan untuk dapat tetap berjalan meski gedung kantor harus tutup. Hal ini menjadi jawaban bagi perusahaan terutama jika terjadi masa-masa seperti masa pandemi saat ini. Kemudahan yang diberikan dan efisiensi serta efektivitas yang bisa dirasakan perusahaan menjadi alasan mengapa layanan dari Machine Vision ini layak untuk dipertimbangkan oleh industri. Selain itu karena Machine Vision merupakan perusahaan lokal, maka perusahaan klien mendapat jaminan kemudahan untuk menghubungi jika terdapat kendala dalam sistem.

Berdasarkan hasil wawancara dengan co-founder dan marketing officer Machine Vision, dalam upaya agar layanan yang disediakan oleh Machine Vision dapat diketahui dan menarik klien untuk menggunakan jasanya, maka Machine Vision mengandalkan implementasi IMC. Dalam keseluruhan implementasi kegiatan IMC dari Machine Vision, tujuan utamanya adalah untuk memberikan pemahaman tentang kemudahan berteknologi, yang berujung pada ketertarikan untuk menggunakan jasa dari Machine Vision. Tentu pada dasarnya, IMC adalah upaya untuk menyampaikan pesan-pesan dari perusahaan yang terkait dan dirasakan oleh target pasarnya dengan tujuan untuk mempengaruhi rasa ingin membeli konsumen. Co-founder dan Marketing Officer Machine Vision menjelaskan bahwa strategi IMC di Machine Vision difokuskan pada pembangunan relasi dengan konsumen maupun calon konsumen yang memiliki ketertarikan pada kemudahan teknologi dan pembuatan konten untuk menjangkau mereka. Dalam hal ini, keputusan pertimbangan strategi IMC dari Machine Vision yang berfokus pada relasi dan konten relevan dengan pemikiran Blakeman, dimana komunikasi dengan target yang memiliki minat terhadap produk atau layanan bisa meningkatkan jangkauan atau jumlah orang yang tertarik untuk melihat pesan yang disampaikan (Blakeman, 2018).

Co-founder Machine Vision menjelaskan dalam wawancara bahwa target pasarnya yaitu industri-industri yang sedang berkembang dan membutuhkan IoT untuk memperlancar proses kerjanya. Perusahaan klien yang menjadi target usaha adalah perusahaan manufaktur multinasional maupun nasional yang mengimplementasi early adapter technology. Secara spesifik, target usaha dari Machine Vision salah satunya adalah perusahaan FMCG (Fast Moving Consumer Goods). Perusahaan jenis ini dipilih karena pengelolaan secara manual bagi perusahaan jenis ini memiliki banyak kelemahan seperti data stock yang tidak terbaharui, perbedaan antara catatan data dengan ketersediaan riil barang, dan mudahnya pemalsuan data. Maka dari itu perusahaan jenis ini tentunya membutuhkan IloT untuk membantu pengelolaan perusahaan agar lebih efektif dan efisien.

Lebih lanjut co-founder menjelaskan perencanaan implementasi IMC pada Machine Vision diawali dengan cara membaca paper atau kajian mengenai permasalahan industri saat ini. Kasuskasus yang dipilih untuk dipelajari adalah yang berkaitan dengan target market. Kemudian kasus-kasus ini dikupas lebih dalam oleh tim dari divisi marketing untuk dapat mengetahui insight dari target market. Setelah itu, dilakukan rapat tim marketing untuk mengatur kegiatan- 
kegiatan yang akan dilaksanakan berdasarkan insight yang sudah diperoleh dan juga ketersediaan anggaran yang ada. Lebih jauh, marketing officer Machine Vision mengakui bahwa sampai saat ini dalam pelaksanaan IMC, anggaran yang disediakan oleh perusahaan masih terbatas. Hal ini menyebabkan IMC mix yang dijalankan harus dikelola sedemikian sehingga dapat tetap berjalan secara efektif.

Marketing officer Machine Vision juga menjelaskan jenis-jenis IMC mix yang telah dijalankan antara lain digital marketing, public relations, direct marketing, sales promotion, dan personal selling. Berdasarkan hasil analisis data yang dilakukan oleh peneliti, terdapat kegiatan IMC Mix yang memberikan dampak besar pada usaha Machine Vision. Namun terdapat juga kegiatan yang lebih bersifat complimentary atau dukungan untuk kegiatan IMC mix lainnya. Berdasarkan dampak tersebut, peneliti mengelompokkan jenis IMC mix yang dilakukan Machine Vision sebagai berikut:

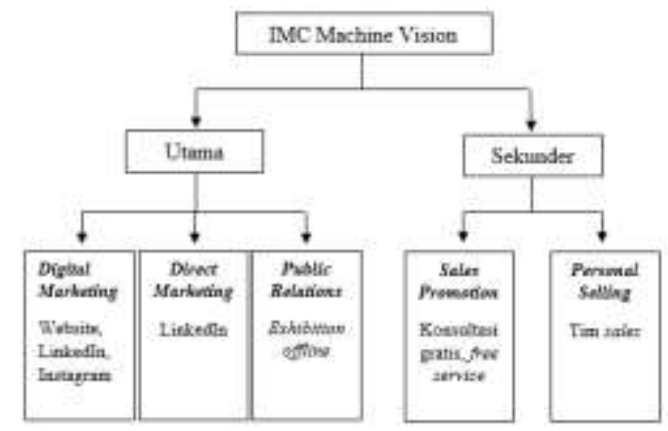

Gambar 1 Klasifikasi IMC Mix Pada Machine Vision

IMC utama dikelompokkan berdasarkan komponen-komponen yang paling berdampak dan berpeluang besar untuk mendapatkan leads atau potential client yang menjadi tolak ukur keberhasilan IMC Machine Vision. Tujuannya selain untuk menciptakan hubungan interaksi dua arah antara penjual dan pembeli, juga untuk menjalin hubungan berjangka panjang.
Bentuk dari kegiatan utama IMC Machine Vision yaitu digital marketing, public relations dan direct marketing. Dalam kelompok IMC sekunder, Machine Vision menggunakan kegiatan personal selling dan juga sales promotion mengikuti alur kegiatan IMC utama. Implementasi kegiatan IMC sekunder ini lebih berfokus pada follow up dari kegiatan IMC utama, sehingga lebih berfungsi untuk mendorong calon klien atau klien untuk menggunakan jasa dari Machine Vision. Berikut adalah penjabaran dari implementasi kegiatan IMC pada Machine Vision:

\section{a. Digital Marketing}

Digital marketing merupakan platform komunikasi alternatif untuk melaksanakan IMC di era digital ini. Digital marketing dilaksanakan dengan berfokus pada pola penggunaan platform digital yang sering digunakan oleh masyarakat saat ini (Teguh \& Ciawati, 2020). Digital marketing berperan besar untuk menyebarluaskan konten dan juga campaign mengenai kemudahan teknologi yang berkaitan dengan permasalahan industri saat ini hingga akhirnya dapat menarik perhatian calon klien. Media yang digunakan untuk menyebarkan konten tersebut adalah website, Linkedln dan juga Instagram. Machine Vision paham betul mengenai maraknya mediamedia yang sifatnya digital terlihat dari upayanya untuk menciptakan konten dan campaign di media sosial dengan tajuk \#MenjadiLebihMudah yang dikaitkan dengan permasalahan pada industri masa kini. Hal ini dilakukan agar klien mendapatkan gambaran kemudahan yang akan mereka dapatkan jika bekerjasama dengan Machine Vision. 
Secara khusus Machine Vision memberikan penekanan pada pengelolaan Linkedln. Linkedln dirasa sebagai platform media sosial yang menjangkau para profesional, sehingga platform ini sesuai untuk mendekati pemilik atau top management industri. Pengelolaan Linkedln Machine Vision dimulai dengan mengganti profil Linkedln pribadi co-founder menjadi profil Machine Vision yang benar-benar profesional dan serius. Hal ini dilakukan karena akun tersebut akan dihubungkan ke beberapa orang pemilik perusahaan yang menjadi target Machine Vision. Kemudian tim marketing membuat dan menyebarkan konten-konten artikel maupun infografis yang memiliki kaitan dengan industri teknologi dalam Linkedln tersebut.

Selain penggunaan Linkedln, salah satu kegiatan digital marketing yang menjadi andalan Machine Vision adalah penyampaian informasi melalui website. Dalam website http://www.machinevision.global/,

Machine Vision memberikan informasi lengkap mengenai tujuan, visi misi, keunggulan, dan layananlayanan yang disediakan oelh Machine Vision. Dalam website ini Machine Vision juga menambahkan video-video dan gambar-gambar contoh program yang dibuatnya. Dengan gambaran tersebut, calon klien dan klien akan lebih mudah membayangkan seperti apa jasa yang diberikan oleh Machine Vision, mengingat usaha IloT masih merupakan usaha yang baru di mata masyarakat umum sehingga dibutuhkan gambaran tersebut. Penggunaan website ini didukung oleh narasumber ahli, dimana dalam wawancaranya narasumber ahli menjelaskan bahwa website merupakan sarana utama untuk perusahaan memperkenalkan dirinya secara profesional. Website yang dikelola dengan baik dapat menumbuhkan kepercayaan klien akan keberadaan dan kinerja dari perusahaan.

Menurut marketing officer dari Machine Vision, dalam website ini juga diunggah artikel-artikel seputar teknologi dan industri. Artikel-artikel ini selain berfungsi sebagai penjelas manfaat dari layanan Machine Vision, juga sebagai upaya untuk Search Engine Optimization (SEO). SEO merupakan usaha untuk meningkatkan organic clicks, yaitu klik ke laman website tanpa menggunakan sponsored links yang akan menghasilkan paid clicks atau klik berbayar. Sebagai contoh, Google, sebagai salah satu search engine yang paling banyak digunakan, akan menampilkan tiga tautan teratas dari website berbayar, baru kemudian dilanjutkan dengan tautan dari website tidak berbayar pada laman pencariannya ketika seseorang memasukkan kata kunci. Disini para pemilik website yang ingin agar lamannya berada di halaman depan pencarian Google, harus menggunakan SEO (Baye et al., 2016). Penulisan artikel dapat menjadi salah satu cara untuk melakukan SEO, dimana konten yang kuat akan mendorong laman untuk naik pada daftar pencarian search engine (Giomelakis \& Veglis, 2015). Maka dari itu Machine Vision melakukan unggah artikel secara berkala untuk meningkatkan jumlah pengunjung pada lamannya. 
Untuk mendukung lebih banyak kunjungan ke website dan menarik perhatian calon klien, Machine Vision juga menggunakan Instagram dengan nama akun @machine.vision. Pada akun Instagram ini, Machine Vision menyampaikan informasi-informasi singkat yang berhubungan dengan campaign mereka tentang kemudahan teknologi secara berkala pada bagian feeds. Sedangkan pada bagian stories diberikan informasi mengenai event dan pencapaian dari Machine Vision. Pada bagian bio diberikan link yang akan menuju pada artikel-artikel yang diunggah pada website. Co-founder dan tim marketing dari Machine Vision masih merasa bahwa Instagram ini merupakan platform penunjang untuk digital marketing. Maka dari itu mereka tidak banyak mengembangkan strategi IMC pada platform ini. Padahal menurut hasil wawancara dengan Person In Charge (PIC) dari perusahaan klien menyatakan bahwa dirinya justru tertarik dengan unggahan pada feeds di Instagram Machine Vision. Selain itu Instagram juga memiliki fitur-fitur untuk mengetahui perilaku konsumen dan berinteraksi dengan mereka. Maka dari itu perlu dilakukan pengembangan pada platform media sosial ini agar lebih efektif. Hal ini juga disetujui oleh narsumber ahli yang dalam wawancaranya menyetujui bahwa saat ini Instagram sudah mulai dilirik oleh para profesional untuk mencari informasi tentang suatu perusahaan. Maka dari itu pengembangan pada platform Instagram dapat mulai dilakukan bahkan untuk perusahaan business to business. b. Direct Marketing

Direct marketing atau pemasaran langsung merupakan salah satu kegiatan IMC yang dapat dipertimbangkan untuk jenis usaha business to business. Melalui kegiatan ini, perusahaan dapat membuka alur komunikasi dua arah dan membina kedekatan dengan target market (Teguh et al., 2019). Berdasarkan wawancara dengan marketing officer Machine Vision, kegiatan direct marketing yang dilakukan oleh Machine Vision dilaksanakan secara kombinasi dengan taktik IMC lainnya terutama digital marketing. Dalam strateginya, Machine Vision melakukan kegiatan tersebut dengan memanfaatkan Linkedln yang juga digunakan untuk menyebarkan konten-konten digital marketing.

Awalnya admin Linkedln dari Machine Vision menyusun terlebih dahulu database berdasarkan profilprofil pada platform Linkedln. Admin melakukan pencarian terhadap orangorang yang menjadi PIC dari perusahaan - perusahaan target Machine Vision. Kemudian admin mengelompokkan dan menyimpan data-data orang yang akan dihubungi tersebut. Setelah mendapatkan database, maka admin Linkedln Machine Vision menghubungi caloncalon klien melalui fitur pesan yang ada. Disini pesan yang disampaikan adalah pengenalan akan Machine Vision yang dibuat lebih personal, dengan cara menyapa nama dari PIC perusahaan dan memperkenalkan keunggulan Machine Vision yang dirasa sesuai dengan kondisi masingmasing perusahaan sasaran. Perlu dipahami bahwa sebelum memulai menghubungi calon-calon klien tersebut, akun Linkedln Machine 
Vision sudah diperbaharui informasinya. Sehingga jika calon klien ada yang membaca pesan dari admin dan ada keraguan, dapat menjadi lebih percaya ketika membuka laman Linkedln dari Machine Vision yang sudah memuat informasi terbaru secara jelas.

Jika ada calon klien yang tertarik oleh karena pesan yang dikirimkan oleh admin, maka disini mulai akan terbuka komunikasi dua arah, dimana calon klien dapat mengajukan pertanyaan kepada admin Machine Vision. Disini peran dari admin menjadi sangat penting. Admin harus mampu membangun kedekatan dengan calon klien yang dihubungi dengan cara direct marketing. Dimulai dengan sigap membalas pesan, dimana pesan tidak boleh dibiarkan tidak terjawab terlalu lama. Kemudian admin juga harus sigap memberikan informasi, baik melalui percakapan atau dapat dibantu dengan informasi yang telah diunggah di website. Admin dapat memberikan link ke website Machine Vision untuk membantu klien mendapatkan informasi yang lebih jelas. Lebih jauh jika klien sudah ingin melakukan pembicaraan yang lebih mendalam mengenai kebutuhan perusahaannya, maka admin dapat memberikan saluran lain yang lebih mudah untuk berkomunikasi secara intens, seperti alamat email, nomor telepon, dan nomor kontak Whatsapp.

Penggunaan Linkedln sebagai sarana untuk direct marketing ini dirasa oleh co-founder maupun marketing officer dari Machine Vision memiliki dampak yang positif. Lebih banyak calon klien yang merespon pesan yang mereka kirimkan melalui platform Linkedln ini. Sebelumnya,
Machine Vision melakukan direct marketing dengan cara email blast. Namun hal ini dirasa tidak efektif karena sangat sedikit yang merespon e-mail tersebut. Maka dari itu sekarang Machine Vision lebih berfokus pada Linkedln untuk aktivitas direct marketing.

Namun ada saran berdasarkan wawancara dengan PIC perusahaan klien, untuk klien yang sudah mengenal Machine Vision, ada baiknya kegiatan email blast tetap dilaksanakan untuk menginformasikan tentang produk atau promosi terbaru dari Machine Vision. Hal ini dikarenakan perusahaan yang sudah menjadi klien tentunya sudah tidak dihubungi lagi melalui Linkedln, namun mereka juga berkemungkinan melakukan repeat buying jika ada produk baru yang diminati. Narasumber ahli dalam wawancaranya juga menyebutkan bahwa direct marketing masih layak untuk digunakan dalam menjalin hubungan dengan klien. Meskipun perlu berhati-hati agar tidak menjadi spam yang malah mengganggu klien.

\section{c. Public Relations}

Public relations merupakan aktivitas untuk membangun relasi, membuat perencanaan strategis, menjangkau stakeholder, hingga membuat program kreatif yang berujung pada pengelolaan reputasi perusahaan (Teguh, Anandari, et al., 2020). Berdasarkan wawancara dengan co-founder Machine Vision, stakeholder utama yang dijaga relasinya oleh Machine Vision adalah Kemenperin. Kemenperin menjadi stakeholder yang memiliki jaringan dengan para pengusaha manufaktur dalam negeri, yang menjadi target 
market dari Machine Vision. Melalui relasinya dengan Kemenperin, Machine Vision memperoleh banyak sekali manfaat. Machine Vision diperkenalkan pada jaringan dari Kemenperin melalui even-event yang mereka adakan seperti exhibition dan talkshow. Dari event-event ini, Machine Vision mendapatkan banyak sekali klien. Sebagai salah satu perusahaan yang diberikan award dan juga direkomendasikan oleh Kemenperin, Machine Vision memiliki reputasi yang baik di mata pelakupelaku usaha manufaktur. Hal ini yang mendorong mereka untuk bersedia menjadi klien dari Machine Vision.

Selain menjalin hubungan baik dengan Kemenperin, Machine Vision juga menjalin hubungan dengan beberapa media massa. Umumnya Machine Vision mengundang media massa untuk melakukan liputan dalam kegiatan-kegiatan mereka, namun masih belum ada tindak lanjut lebih jauh untuk kegiatan media relations lainnya. Disini Machine Vision masih dapat mengembangkan kegiatan public relations agar tidak hanya berfokus pada Kemenperin saja. Ada banyak stakeholder lain yang dapat mulai didekati juga seperti asosiasi, lembaga pemerintahan lainnya, media massa, yayasan, dan lain sebagainya.

\section{d. Sales Promotion}

Sales promotion merupakan salah satu elemen dalam IMC yang menekankan pemberian insentif untuk menstimulasi konsumen agar mempercepat proses pembelian atau meningkatkan jumlah pembelian (Familmaleki et al., 2015). Dari wawancara dengan marketing officer Machine Vision, selama ini kegiatan sales promotion yang dilakukan oleh Machine Vision hanya sebagai upaya tindak lanjut atau dorongan agar klien mau melakukan kerjasama. Bila ada calon klien yang sudah berhasil didekati dengan menggunakan kegiatan IMC utama, namun masih ada keraguan untuk menjalin kerjasama dengan Machine Vision, maka digunakan sales promotion untuk menyakinkan mereka. Caranya adalah dengan pemberian konsultasi gratis dan gratis biaya tambahan untuk pertama kali pemakaian, sehingga calon klien merasa lebih yakin dan bersedia untuk meneken kontrak dengan Machine Vision.

Berdasarkan wawancara dengan PIC dari perusahaan klien, sales promotion ini membantu mereka untuk merasa lebih yakin karena tidak membeli kucing dalam karung. Pihak Machine Vision bersedia memberikan konsultasi gratis dahulu, sehingga perusahaan bisa memahami hal-hal apa saja yang mereka butuhkan. Kemudian tim Machine Vision juga bersedia untuk datang meninjau kondisi lapangan atau pabrik terlebih dahulu, tanpa ada biaya, sebelum memberikan proposal penawaran program. Hal ini membuat program yang ditawarkan sesuai dengan kebutuhan klien, dan klien juga bisa merasakan komitmen dari Machine Vision. Hal lain yang juga dirasakan oleh klien adalah adanya bantuan service gratis jika program mengalami kendala selama penggunaan. Hal ini tentunya sangat krusial karena program akan digunakan dalam jangka panjang dan menyimpan datadata penting, hehingga ketersediaan maintenance service menjadi salah satu hal wajib, apalagi jika dibantu dengan beberapa service gratis. Selain 
untuk mendorong agar calon klien mau bekerjasama, kegiatan sales promotion juga digunakan untuk mendorong klien yang sudah pernah menggunakan jasa dari Machine Vision untuk re-puchase. Disini Machine Vision menawarkan untuk menambah program atau layanan dengan harga khusus untuk klien yang sudah pernah menggunakan jasa Machine Vision. Hal ini juga berhasil mendorong klien untuk melakukan membuat kontrak kerjasama baru dengan Machine Vision.

\section{e. Personal Selling}

Personal selling merupakan salah satu kegiatan IMC yang mengandalkan salesperson. Kegiatan ini memungkinkan terjadinya interaksi dua arah antara perusahaan dengan calon konsumen, dimana salesperson dapat menggali feedback dari calon konsumen dan mendorong mereka untuk melakukan pembelian (Teguh, Benita, et al., 2020). Dalam pelaksanaan personal selling $\mathrm{di}$ Machine Vision, tim sales memegang peranan utama untuk melancarkan kegiatan promosi maupun penjualan. Seperti yang dikatakan oleh $\mathrm{Co}$ founder dan Marketing Officer Machine Vision, divisi sales bertugas untuk mendampingi klien dan juga menjelaskan produk-produk Machine Vision pada klien di lapangan. Disini tim sales turun ke lapangan ketika sudah ada calon klien yang terjaring dari kegiatan IMC utama untuk lebih mendekati dan meyakinkan mereka.

Sayangnya ada kelemahankelemahan yang dirasakan oleh klien saat berhadapan dengan tim sales yang dikirimkan oleh Machine Vision. Beberapa kritikan dari PIC perusahaan klien diantaranya adalah bahasa tim sales yang kurang formal pada klien yang umurnya lebih senior di lingkungan industri yang bersifat profesional. Selain bahasa yang kurang formal, penjelasan mengenai produk dari tim sales juga dirasa kurang runut dan melompat-lompat sehingga sulit untuk dipahami. Menghadapi hal ini, Machine Vision harus memberikan pelatihan khusus sebelum menurunkan tim sales ke lapangan agar tercipta transfer knowledge yang baik antara Machine Vision dengan perusahaan klien. Tim sales juga perlu dibekali pemahaman tentang karakteristik dari perusahaan klien, maupun PIC yang akan mereka temui. Karena produk yang ditawarkan adalah produk baru yang wujudnya sulit untuk dibayangkan, penjelasan yang terlalu teknis malah bisa jadi membingungkan. Namun jika hanya dijelaskan di permukaan, maka klien bisa jadi merasa kurang yakin. Maka dari itu tim sales juga harus dibekali dengan promotional kit, seperti booklet, video, dan simulasi produk, yang dapat membantu mereka memberikan gambaran kepada calon klien.

Terdapat beberapa sorotan menarik terlepas dari adanya respon positif terhadap IMC Machine Vision. Sampai saat ini Machine Vision masih enggan untuk melakukan kegiatan advertising. Advertising atau periklanan merupakan upaya komunikasi persuasif melalui media berbayar, yang berguna untuk menyampaikan informasi, memberikan ide atau gagasan, serta menjual barang (Fenyapwain, 2013). Machine Vision merasa enggan menggunakan advertising karena takut akan biaya advertising yang tinggi. Selain itu, dirasa jika target sasaran dari Machine Vision belum tentu akan 
merasakan dampak dari adveritising yang berbiaya tinggi tersebut. Sayangnya pihak Machine Vision memang belum banyak mengeksplorasi berbagai jenis kegiatan advertising beserta biayanya. Padahal ada berbagai jenis advertising yang dapat dipertimbangkan dengan biaya yang lebih dapat diatur, misalnya seperti Google Ads. Google Ads dapat memberikan banyak financial value, dengan cara menarik target kepada halaman website perusahaan. Namun perlu dipahami bahwa Google Ads juga harus dikelola dengan baik agar bisa memberikan hasil maksimal sesuai dengan dana yang dikeluarkan (Gligorovski et al., 2018).

Selain advertising, Machine Vision juga belum pernah menjajaki kemungkinan untuk melakukan event sponsorship. Event sponsorship adalah kegiatan menampilkan merek atau produk pada suatu kegiatan yang dirasa sesuai dengan nilai-nilai dari merek atau produk tersebut, dengan cara memberikan dukungan berupa dana atau produk dari perusahaan pemilik merek. Tujuan utama dari pemberian sponsorship dalam suatu event adalah meningkatkan kesadaran audiens dari event terhadap merek, produk maupun perusahaan sponsor. Lebih lanjut, event sponsorship dapat mendorong awareness, meningkatkan pemahaman konsumen akan produk, mendorong konsumen untuk mencoba produk, mendorong konsumen untuk melakukan pembelian, meningkatkan frekuensi penggunaan produk, dan menciptakan loyalitas konsumen (Alim, 2005). Bentuk dari sponsorship pada event antara lain pemasangan umbul-umbul, rotating banner, banner up, banner- $x$, dan neon box tentang produk, pemasangan logo pada backdrop dan media lain milik event, serta pendirian booth untuk pameran atau penjualan produk (Amijaya, 2010). Alasan tidak dilakukannya event sponsorship oleh
Machine Vision masih sama dengan tidak digunakannya advertising, yaitu masalah budget dan dampak terhadap target. Sesungguhnya kegiatan sponsorship ini masih dapat dipertimbangkan kembali karena sponsorship berguna untuk meningkatkan kesadaran merek, meningkatkan citra merek, dan meningkatkan volume penjualan (Chitty et al., 2015). Namun memang karena sudah memiliki hubungan baik dengan Kemenperin dan banyak mengikuti event tidak berbayar dari Kemenperin membuat Machine Vision masih enggan untuk mempertimbangkan event-event lainnya.

Selain keengganan menggunakan variasi kegiatan $I M C$, hal lain yang juga perlu menjadi pertimbangan Machine Vision adalah mengenai relasi dengan Kemenperin. Kebergantungan Machine Vision terhadap dukungan dari Kemenperin dapat menjadi ancaman, mengingat bahwa fokus, budget, dan kebijakan dari Kemenperin nantinya bisa berubah seiring pergantian periode. Jika terus menerus bergantung pada relasi Kemenperin, dikhawatirkan kegiatan IMC dari Machine Vision akan terhenti di strategi yang sama seperti saat ini. Beberapa ancaman lainnya adalah mengenai kompetitor. Perlu dipahami memang kegiatan IMC dari Machine Vision masih cenderung bersifat low budget dan banyak mengandalkan bantuan dari Kemenperin. Jika Machine Vision tidak segera melakukan inovasi kegiatan IMC, maka dikahwatirkan kemunculan kompetitor yang memiliki budget IMC yang lebih besar dapat menggerus pasar yang telah diperoleh Machine Vision. Hal ini dapat terjadi juga karena Machine Vision selama ini masih berfokus pada perolehan konsumen untuk mendapatkan kontrak kerjasama secara langsung. Belum banyak kegiatan IMC dari Machine Vision yang mengarah pada pembangunan brand 
equity. Brand equity atau ekuitas merek adalah seperangkat aset dan liabilitas yang melekat pada suatu merek (biasanya berupa nama, logo, atau simbol), yang memberikan nilai terhadap suatu produk atau perusahaan di mata pelanggan (Chan, 2010). Maka dari itu Machine Vision masih harus melakukan eksplorasi lagi untuk mengembangkan perencanaan kegiatan IMC kedepan. Selain itu juga perlu melakukan penyisihan budget yang sudah dikalkulasi agar kegiatan IMC dapat menjangkau pasar baru.

\section{Kesimpulan}

Berdasarkan hasil penelitian, dapat dilihat bahwa strategi IMC memberikan kontribusi positif kepada perusahaan penyedia jasa IIoT. Manfaat yang diperoleh oleh perusahaan tersebut antara lain memperoleh awareness dimana pasar potensial jadi mengetahui keberadaan mereka. Kemudian kegiatan IMC juga pada ujungnya memungkinkan perusahaan untuk memperoleh klien dan mempertahankan hubungan jangka panjang dengan klien tersebut. Terdapat beberapa jenis IMC Mix yang memiliki dampak signifikan bagi perusahaan penyedia jasa IloT, namun ada beberapa yang hanya berguna sebagai pendukung. Manfaat dari strategi IMC untuk industri 4.0 adalah mendapatkan potential clients maupun mempertahankan klien yang sudah ada. Strategi IMC dimulai dengan penentuan target pasar. Secara khusus target pasar dari Machine Vision adalah industri-industri yang sedang berkembang dan membutuhkan IIoT untuk memperlancar proses kerjanya. Sedangkan pesan utama yang diusung dalam IMC adalah pemahaman tentang kemudahan berteknologi. Anggaran yang disediakan untuk IMC masih terbatas dan perlu untuk dipikirkan penambahan budget kedepannya.
Dalam pelaksanaan IMC mix, dapat diklasifikasikan menjadi dua kelompok, yaitu kelompok utama dan kelompok sekunder berdasarkan dampaknya terhadap perolehan leads atau potential clients. Kelompok utama diisi oleh 3 komponen, digital marketing, public relations dan direct marketing. Sedangkan kelompok sekunder diisi oleh personal selling dan sales promotion. Kegiatan digital marketing dilakukan melalui penggunaan website, Instagram dan juga Linkedin. Upaya tersebut didukung dengan pembuatan konten dan juga campaign dengan tajuk \#MenjadiLebihMudah yang menggambarkan mengenai kemudahan teknologi. Machine Vision berupaya untuk menciptakan konten yang dekat dengan isu-isu industri saat ini agar audiens maupun calon klien merasa relate dengan permasalahan tersebut. Kegiatan direct marketing dilakukan dengan memanfaatkan konten-konten digital marketing dan menghubungi calon klien melalui platform Linkedln. Kegiatan public relations sejauh ini dirasa paling berdampak. Melalui kegiatan public relations, Machine Vision mampu menjalin relasi dengan Kemenperin dan memperoleh benefit berupa event offline gratis untuk bertemu secara langsung dengan target pasarnya. Sedangkan, kegiatan sales promotion dan personal selling lebih digunakan sebagai follow up dari kegiatan IMC utama maupun untuk mendorong klien melakukan re-puchase.

Terlepas dari IMC yang berkontribusi positif, ditemukan juga beberapa ancaman yang dapat mempengaruhi keberlangsungan usaha Machine Vision sekarang maupun dimasa yang akan datang. Ancaman yang pertama adalah keenganan Machine Vision untuk menggunakan variasi kegiatan IMC yang berbayar seperti advertising dan event 
sponsorship. Hal ini dikarenakan Machine Vision merasa bahwa dengan kegiatan IMC yang tidak memerlukan banyak budget seperti sekarang sudah menunjukkan kontribusi positif terhadap penjualan produk Machine Vision. Selain itu Machine Vision juga masih mengkhawatirkan banyaknya biaya yang keluar untuk periklanan dan sponsorship belum tentu sebanding dengan dampaknya terhadap penjaringan calon konsumen. Hal ini sangat disayangkan mengingat saat ini telah sangat banyak jenis advertising dan sponsorship yang dapat diatur budget-nya, serta dapat dikelola untuk memaksimalkan brand awareness maupun penjualan produk.

Ancaman berikutnya datang dari kebergantungan Machine Vision terhadap Kemenperin. Dikhawatirkan, Kemenperin akan mengganti kebijakan dan juga anggaran di periode selanjutnya karena fokusnya tidak hanya untuk industri 4.0 saja. Hal ini tentunya berdampak sangat besar kepada Machine Vision, karena kegiatan IMC utama Machine Vision banyak mengandalkan jaringan dari Kemenperin. Selama ini Machine Vision banyak diuntungkan juga dari kegiatankegiatan tidak berbayar yang diadakan oleh Kemenperin untuk mendorong percepatan laju industri 4.0. Machine Vision diharapkan dapat mulai merancang strategi lain yang tidak banyak bergantung pada Kemenperin, walaupun tetap menjaga relasi dengan Kemenperin. Sehingga jika nantinya Kemenperin sudah tidak lagi mengadakan kegiatan gratis untuk industri 4.0, Machine Vision tidak kelabakan dan baru mulai mencari alternatif saat sudah terlambat.

Kemudian ancaman terakhir adalah kemunculan kompetitor dengan budget IMC yang lebih besar yang bisa menguasai pasar. IMC dari Machine Vision yang masih bersifat low budget, harus ditinjau dan direncanakan ulang untuk kedepannya. Hal ini diperlukan untuk menghadapi ancaman dan persaingan kedepan yang semakin ketat. Perlu dipikirkan untuk menambahkan kegiatan advertising berbayar maupun sponsorship agar IMC Machine Vision dapat menjangkau pasar yang lebih luas. Kedepannya, Machine Vision tidak boleh hanya berfokus pada penjualan langsung dari produknya, namun perlu untuk meningkatkan brand equity. Hal ini untuk menghindari pesaing yang lebih kuat dengan modal besar mengalahkan Machine Vision dalam sekejap karena brand equity dari Machine Vision masih lemah.

\section{Referensi}

Adhianti, A. A., \& Herlinda, H. (2020). Strategi Komunikasi Pemasaran $7 \mathrm{P}$ Pengelola Museum Sejarah Jakarta Dalam Upaya Meningkatkan Daya Tarik Wisatawan Mancanegara. Scriptura, 10(1), 34-42. https://doi.org/10.9744/scriptura.10.1 $.34-42$

Adrian, A. (2019). Kesiapan Sumber Daya Manusia Indonesia Dalam Era Industri 4.0. In Jurnal Manajemen \& Bisnis Jayakarta (Vol. 1, Issue 01). http://journal.stiejayakarta.ac.id/inde x.php/JMBJayakarta/article/view/12

Alim, Z. (2005). Pelaksanaan Sponsorship Dampaknya Terhadap Brand Image Pada Clothing Linecoltd Sumur Bandung.

Amijaya, F. S. (2010). Pengaruh Event Sponsorship Acara LA. Lights Indiefest terhadap Brand Image LA. Lights pada PT. Djarum di Bandung [Universitas Widyatama]. https://repository.widyatama.ac.id/x mlui/handle/123456789/2542

Andretti, Y. R., \& Arifin, H. (2016). Integrated Marketing Communications Dalam Komunikasi Pemasaran PT. DBL Indonesia. Jurnal Komunikasi Massa, 13(2), 253-266. 
https://www.jurnalkommas.com/inde x.php?target=isi\&jurnal=INTEGRATE D MARKETING COMMUNICATIONS DALAM KOMUNIKASI PEMASARAN PT. DBL INDONESIA

Anggito, A., \& Setiawan, J. (2018). Metodologi Penelitian Kualitatif. Jejak Publisher.

Baye, M. R., De los Santos, B., \& Wildenbeest, M. R. (2016). Search Engine Optimization: What Drives Organic Traffic to Retail Sites? Journal of Economics \& Management Strategy, 25(1), 6-31. https://doi.org/10.1111/jems.12141

Blakeman, R. (2018). Integrated Marketing Communication: Creative Strategy from Idea to Implementation. Rowman \& Littlefield.

Chan, A. (2010). Pengaruh Ekuitas Merek Terhadap Proses Keputusan Pembelian Konsumen : Studi Kasus Bank Muamalat Indonesia Cabang Bandung. Jurnal Administrasi Bisnis, $6(1), 43-62$.

Chitty, Barker, L., \& Shimp, V. (2015). Integrated Marketing Communication. Cengage Learning.

Chrismardani, Y. (2014). Komunikasi Pemasaran Terpadu : Implementasi Untuk UMKM. Neo-Bis, 8(2), 179-189. https://doi.org/10.21107/NBS.V8I2.47 2.G442

Daniel, S. P., \& Sam, A. G. (2011). Research Methodology. Gyan Publishing House.

Familmaleki, M., Aghighi, A., \& Hamidi, K. (2015). Analyzing the Influence of Sales Promotion on Customer Purchasing Behavior. International Journal of Economics \& Management Sciences, 4(4), 1-6. https://doi.org/10.4172/21626359.1000243

Fenyapwain, M. M. (2013). Pengaruh Iklan Politik Dalam Pemilukada Minahasa Terhadap Partisipasi Pemilih Pemula di Desa Tounelet Kecamatan Kakas.
ACTA DIURNA KOMUNIKASI, 2(1). https://ejournal.unsrat.ac.id/index.ph p/actadiurnakomunikasi/article/view/ 975

Firmansyah, A. (2018). Kajian Kendala Implementasi E-Commerce Di Indonesia. Masyarakat Telematika Dan Informasi : Jurnal Penelitian Teknologi Informasi Dan Komunikasi, 8(2), 127-136. https://doi.org/10.17933/mti.v8i2.107

Fitrah, M., \& Luthfiyah. (2018). Metodologi Penelitian: Penelitian Kualitatif, Tindakan Kelas \& Studi Kasus. CV Jejak Publisher.

Gilchrist, A. (2016). Industry 4.0: The Industrial Internet of Things. Apress.

Ginting, M. L. (2015). STRATEGI KREATIF DALAM MENDUKUNG KEWIRAUSAHAAN (Studi Kasus Pemilihan Strategi Kreatif dalam Memproduksi Iklan Produk Minuman sebagai Bentuk Mendukung Kegiatan Wirausaha). In Komunikatif, Jurnal Ilmiah Komunikasi (Vol. 4, Issue 1). http://journal.wima.ac.id/index.php/K OMUNIKATIF/article/view/1622

Giomelakis, D., \& Veglis, A. (2015). Employing Search Engine Optimization Techniques in Online News Articles. Studies in Media and Communication, 3(1), 22-33. https://doi.org/10.11114/smc.v3i1.683

Gligorovski, V., Mancheski, G., \& Angeleski, M. (2018). The Engagement Of Audience In Seo Of An Actual Web Page Using Google Ads. International Balkan and Near Eastern Social Sciences Congress Series $X$. IBANESS Congress Series, 127-136.

Green, J. (2011). Advertising. The Rosen Publishing Group, Inc.

Herdiansyah, H. (2010). Metodologi Penelitian Kualitatif : Untuk Ilmu-ilmu Sosial. Salemba Humanika.

Kagermann, H., Anderl, R., Gausemeier, J., Schuh, G., \& Wahlster, W. (2016). 
Industrie 4.0 in a Global Context: Strategies for Cooperating with International Partners. Acatech Study.

Keke, Y. (2016). Komunikasi Pemasaran Terpadu Terhadap Brand Awareness. Jurnal Manajemen Bisnis Transportasi Dan Logistik, 2(1), 172-186. https://www.researchgate.net/public ation/325967152

Kotler, P., \& Armstrong, G. (2012). Principles of Marketing. Pearson Education.

Kotler, P., \& Lane, K. K. (2016). Marketing Management. Pearson Education.

Kuada, J. (2016). Research Methodology: A Project Guide for University Students. Samfundslitteratur.

Kusniadji, S. (2017). Strategi Komunikasi Pemasaran dalam Kegiatan Pemasaran Produk Consumer Goods (Studi kasus Pada PT Expand Berlian Mulia Di Semarang). In Jurnal Komunikasi (Vol. 8, Issue 1). https://doi.org/10.24912/JK.V811.49

Morissan. (2010). Periklanan Komunikasi Pemasaran Terpadu. Prenadamedia Group.

Noor, J. (2016). Metodologi Penelitian: Skripsi, Tesis, Disertasi \& Karya Ilmiah. Prenada Media.

Permata, D., \& Rahayu, S. (2015). "SI LOKO" SEBAGAI MASKOT PT. KERETA API INDONESIA. In Komunikatif, Jurnal Ilmiah Komunikasi (Vol. 4, Issue 2).

http://journal.wima.ac.id/index.php/K OMUNIKATIF/article/view/768

Prasetyo, B. D., Febriani, N. S., Asmara, W. W., Tamitiadini, D. D., Destriny, N. A., Avina, D. A. A., \& Illahi, A. K. (2018). Komunikasi Pemasaran Terpadu: Pendekatan Tradisional Hingga Era Media Baru. UB Press.

Prasetyo, H., \& Sutopo, W. (2018). Industri 4.0: Telaah Klasifikasi Aspek Dan Arah Perkembangan Riset. J@ti
Undip : Jurnal Teknik Industri, 13(1),

17-26.

https://doi.org/10.14710/jati.13.1.17-

26

Rahargo, U. P., \& Jannah, L. M. (2020). Tantangan Dalam Pengembangan Program Pelatihan Balai Diklat Industri Di Era Revolusi Industri 4.0. Kebijakan: Jurnal Ilmu Administrasi, 11(2), 1-9. https://doi.org/10.23969/kebijakan.v1 1 i2. 2894

Rehman, S. U., \& Ibrahim, M. S. (2011). Integrated Marketing Communication and Promotion. Researchers World, Journal of Arts, Science \& Commerce, International Refereed Research Journal, 2(4). https://papers.ssrn.com/sol3/papers.c fm?abstract_id $=2383065$

Rismayanti, R. (2016). Integrated Marketing Communications (IMC) di PT Halo Rumah Bernyanyi. Jurnal ILMU KOMUNIKASI, 13(2), 253-266. https://doi.org/10.24002/jik.v13i2.835

Rusmana, A. (2019). The Future of Organizational Communication In The Industrial Era 4.0: Book Chapter Komunikasi Organisasi. Media Akselerasi.

Satya, V. E. (2018). Strategi Indonesia Menghadapi Industri 4.o. Info Singkat, 10(9), 19-24.

Teguh, M., Anandari, P., \& Bungin, B. (2020). Aktivitas Public Relations Di Mall Ciputra World Surabaya. Communicology: Jurnal Ilmu Komunikasi, 8(1), 1-17. http://journal.unj.ac.id/

Teguh, M., Benita, A., \& Dewi, N. K. A. S. U. (2020). Pemanfaatan Komunikasi Pemasaran Terpadu Pada UMKM Snack Indochip. Journalism, Public Relation and Media Communication Studies Journal (JPRMEDCOM), 2(1), 40-55. https://doi.org/10.35706/JPRMEDCO M.V211.3748 
Teguh, M., \& Ciawati, S. T. (2020).

Perancangan Strategi Digital Marketing Communication Bagi Industri Perhotelan Dalam Menjawab Tantangan Era Posmodern. Bricolage : Jurnal Magister Ilmu Komunikasi, 6(01), 51-64. https://doi.org/10.30813/bricolage.v6i 01.2067

Teguh, M., Pascarina, P. A., \& Laurentsia, J. S. (2019). Strategi Intregrated Marketing Communication Bagi Usaha Jasa Pengembangan Sumber Daya Manusia: Studi Kasus Pada PT TQI. In Public Relations Dan Periklanan Menghadapi Revolusi Industri 4.o (pp. 185-196). Buku Litera Yogyakarta.

Uslu, B., Eren, T., Gür, Ş., \& Özcan, E. (2019). Evaluation of the Difficulties in the Internet of Things (IoT) with
Multi-Criteria Decision-Making.

Processes, 7(3), 164.

https://doi.org/10.3390/pr7030164

Ustundag, A., \& Cevikcan, E. (2017). Industri 4.0: Managing the Digital Transformation. Springer International Publishing Switzerland.

Widagdo, B., \& Rofik, M. (2019). Internet of Things as Engine of Economic Growth in Indonesia. Indonesian Journal Of Business And Economics, 2(1). https://doi.org/10.25134/ijbe.v2i1.162 5

Yusuf, A. M. (2016). Metode Penelitian Kuantitatif, Kualitatif \& Penelitian Gabungan. Prenada Media. 